\title{
A Genetic Polymorphism of Interleukin 10 Gene at Position-1082 In Iraqis Patients with type 1 diabetes of
}

\author{
Ibtesam, Badday Hassan ${ }^{1}$; Azdihar, Mohammed Jasem² ;Haneen Akram \\ Habeeb $^{3}$
}

Received : 7/12/2017

* University of Diyala. college of Education for pure science, Department of biology.

${ }^{2}$ University of Diyala. College of Science, Department of Biology .

${ }^{3}$ Ministry of Education. Directorate of curricula and books, Biological Unit.

${ }^{1}$ Corresponding aouther:ibtesambh67@gmail.com

\begin{abstract}
:
The aim of this study was to evaluate the frequency of polymorphism of interleukin-10 Gene at position -1082 of the promoter region (IL-10 ${ }_{-1082}$ SNP) in T1D and in healthy. The subjects were determined in 39 Iraqi patients, (12 males \& 27 females; $15.65 \pm 1.79$ years) and 21 controls (7 male and 14 female; $14.66 \pm 3.43$ years) by polymerase chain reaction-specific sequence primer (PCR-SSP) assay, followed by electrophoresis on agarose-gel. The results revealed that comparing IL10 ${ }_{-1082}$ genotypes and alleles between T1D patients and controls it was observed that frequency of GA genotype was significantly higher $(56.41 \mathrm{vs} .42 .85 \%$; $\mathrm{RR}=23.7)$. may be considered as a risk factor for T1D While A allele was not significantly in patients contrast to controls, $(41.03 \mathrm{vs} .40 .48 \%$; RR $=0.9)$ and the associated EF values were 1.73and 1.02, respectively. In contrast, GG genotype and $G$ allele (30.76vs. $58.97 \%, \mathrm{P}=0.579$ respectively) frequencies were significantly decreased in patients, compared to controls (38.09vs. 59.52\%; $\mathrm{P}=1.000)$, and the associated PF values were 0.72 and 0.98 , respectively. Similar observations were made in AA genotype. These findings suggest that IL10 1082 polymorphism showed associations (positive and negative) with T1D in the samples of Iraqi patients . Therefore, the functional role of such $I L 10_{-1082}$ might have been altered due to the deviations of some genotype and allele frequencies.
\end{abstract}

*Keyword: Polymorphism, IL10, Diabetes Type 1 ,

\section{Introduction:}

Diabetes is a chronic disease which influences over 3 million people in the UK ; about $10 \%$ Type 1 diabetes and residual 90\% have Type 2 diabetes [1]. T1D is a serious autoimmune disease affecting millions of people worldwide characterized by the destruction of the insulinproducing islet $\beta$ cells [2]. T1D usually begins in childhood, adolescence, or early adulthood, but it may also start later in adult life [1], [2].Everyone needs insulin hormone to keep their blood glucose at a normal level. But with T1D, the pancreatic gland not synthesis insulin or make very little of it [3]. T1D results from a T cell-mediated destruction of insulin-producing pancreatic $\beta$ cells. Little is known on local factors contributing to migration of $\mathrm{T}$ cells to pancreatic tissue [4]. Cytokines play as pleiotropic polypeptides regulating inflammatory and immune responses through activity on cells. They provide important signals in the 


\section{AL-Qadisiyah Journal of pure Science Vol.23 No. $1 \quad$ Year 2018}

pathophysiology of a range of diseases, including T1D [5], [6].There is increasing evidence showing that polymorphisms in cytokine genes may play an important role in modulate the immune response. Numerous cytokines have been shown to participate in the pathogenesis of T1D [7], [8]. As gene polymorphisms can influence in cytokine production or function, they may potentially contributed to genetic predisposition to the disease, as at TGF-B1,TNF-a , IL$1 \beta$, IL-4, IL-6, IL-18, and certain chemokines have proposed to be involved in the events result in both forms of diabetes. [11], [10], [9]. Work as mediators of inflammation [12]. Further supply for inflammation to contribute to diabetes comes from researchers to examine the role of inflammatory cytokines in diabetic such as IL-10, an 18-kDa glycoprotein plays a key role in homeostatic control of inflammatory and immune responses. It is produced by Thelper 2 (Th2) cells and a wide variety of cell types including B cells, monocytes, macrophages, keratinocytes, and many tumor cells [13], [14]. Its gene was defined to be located on chromosome $1(1 \mathrm{q} 31-1 \mathrm{q} 32)$, and to have many polymorphic sites in the promoter region $[15,16]$. IL-10 cytokine is required for regulating immune functions by promoting the widespread suppression of immune responses through its pleiotropic effects [17]. The association of IL-10 in immunological diseases like multiple sclerosis, nephrotic syndrome and type-1 diabetes is well established [18], [19], and it is a potent inhibition of the proinflammatory cytokines and chemokine's [21]. Immunosuppressive effects of IL-10 involve both inhibition of cytokine synthesis (e.g., TNF-a, IL-6) and their biological activities on target cells [22]. Nowadays, elevated interleukin (IL)-10 serum levels are associated with improved endothelial vasoreactivity in patients with coronary artery disease (CAD) [23 ]. IL10 as critical cytokines for inducing anti-TSHR antibodies and eliciting Graves' hyperthyroidism in mice [24]. IL-10 is sufficient to drive pathogenic autoimmune responses and accelerates diabetes via an ICAM-1-dependent pathway [25]. One study suggests that the genotypes related with a low production of IL-10 may be associated with the occurrence of toxoplasmic retinochoroiditis [27]. Previous studies tested the role of IL-10 in diabetes have been primarily directed toward the pancreatic cells and the pathogenesis of type 1diabetes performed on pancreatic tissue demonstrated that treatment with IL-10 reduced the severity of insulitis, prevented cellular infiltration of islet cells, and promoted normal insulin production by beta cells. Taken together these results indicate IL-10 suppresses the induction and progression of autoimmune pathogenesis associated with diabetes mellitus and suggest a potential therapeutic role for this cytokine in this autoimmune disease. [25], [26], [28] Polymorphisms related to IL-10-1082 GG and IL-6-174 CC genotypes may be considered as a risk factor for type 2 diabetes mellitus among Egyptian subjects with a potential impact on family counseling and management. [13], [22]. Effects of IL-10, a large range of disorders 
has been reported due to the misregulation of IL-10. In situations of IL-10 deficiencies [28]. For all previous information present study focused on the Interleukins 10-1082 in T1D of Iraqi patients.

\section{Materials and methods:}

\section{Subjects}

The diagnosis and extent of disease was determined by conventional clinical the patients attended the General Hospital of Baquba for diagnosis and treatment during the period October 2015 - June 2016 which was based on clinical . According to diagnosis, after an overnight fasting of $10-12 \mathrm{~h}$ in fasting state for all investigations. Blood samples were collected in EDTA. The samples were stored frozen at $-20 \mathrm{C}$ or below in vials for storage from 39 ; (12 males \& 27 females; $15.65 \pm 1.79$ years). T1D patients and 21 randomly selected healthy controls (HC). The patients were: Age rang mean \pm S.E. comparison, with 21 apparently healthy controls ( 7 males \& 14 females; $14.26 \pm 1.43$ years) and ethnicity (Iraqi Arabs) was also enrolled in the study.

\section{Detection of IL10 Polymorphism}

Genomic DNA was extracted from EDTA blood using Wizard Genomic DNA Purification Kit (Promega, USA). The polymorphism was detected at -1082 and IL-10 positions of the promoter region $\left(I L 10_{-1082}\right)$ by polymerase chain reaction-specific sequence primer (PCRSSP) assay, followed by electrophoresis on $2 \%$ agarose-gel, by using CTS-PCRSSP Tray Kit (Heidelberg, Germany). The thermo cycling conditions were: initial denaturation at $94^{\circ} \mathrm{C}$ for 2 minutes, followed by denaturation at $94^{\circ} \mathrm{C}$ for 15 seconds, and then 10 cycles of annealing and extension at $65^{\circ} \mathrm{C}$ for 60 seconds. This was followed by denaturation at $94^{\circ} \mathrm{C}$ for 15 seconds, and then 20 cycles of annealing $61^{\circ} \mathrm{C}$ at 50 seconds and extension at $72^{\circ} \mathrm{C}$ for 30 seconds.

\section{Statistical Analysis}

Geno types of $I L 10_{-1082}$ SNP were presented as percentage frequencies, and significant differences between their distributions in T1D patients and controls were assessed by twotailed Fisher's exact probability $(\mathrm{P})$. In addition, relative risk (RR), etiological fraction (EF) and preventive fraction $(\mathrm{PF})$ were also estimated to define the association between a geno type with the disease. These estimations were calculated by using the WINPEPI computer programs for epidemiologists. The latest version of the WINPEPI package is available free online at http://www.brixtonhealth.com.

\section{Rustles:}

Genetic polymorphism of $I L 10$ gene was determined in the promoter region at position -1082 $\left(I L 10_{-1082} \mathrm{SNP}\right)$, which was presented with three genotypes (GG, GA and AA) that corresponded to two alleles $(G$ and $A)$. Among T1D patients significant difference was observed between the observed and expected frequencies of the three genotypes $(\mathrm{P} \leq$ 0.300). While in controls, (a good agreement with Hardy-Weinberg equilibrium; HWE), however comparing of patients to controls revealed some significant differences (Table -1). The frequencies of AG genotype was significantly higher (56.41vs. 42.85\%; RR =23.7).It may be considered as a risk factor for T1D, while A allele was not significantly in patients contrast to controls, $(41.03 \mathrm{vs} .40 .48 \%$; RR $=0.9)$ and the associated $\mathrm{EF}$ values were 1.73and 
1.02, respectively. In contrast, GG genotype and $G$ allele $(30.76 v$ s. $58.97 \%, \mathrm{P}=0.579$ respectively) frequencies were significantly decreased in patients, compared to controls (38.09vs. 59.52\%; $\mathrm{P}=1.000$ ), and the associated $\mathrm{PF}$ values were 0.72 and 0.98 , respectively . The preventive fractions (PFs) of such negative associations were 0.72 and 0.98 , respectively . Similar observations were made in AA genotype (12.82vs. $19.04 \%, \mathrm{P}=0.706$ respectively) and the associated PF value was 0.63 . (Table -2).

Table 1: Observed numbers and percentage frequencies and Hardy-Weinberg $(\mathrm{H}-\mathrm{W})$ equilibrium of IL-10-1082 genotypes and alleles in Diabetes Type 1) patients and controls.

\begin{tabular}{|c|c|c|c|c|c|c|c|c|}
\hline \multirow[t]{2}{*}{ Groups } & & & \multicolumn{5}{|c|}{ IL-10- ${ }_{1082}$ Genotypes or alleles } & \multirow{2}{*}{$\begin{array}{c}\mathbf{H}-\mathbf{W} \\
X^{2} \mathbf{P} \leq\end{array}$} \\
\hline & & & GG & GA & AA & $G$ & $A$ & \\
\hline \multirow{4}{*}{$\begin{array}{l}\text { Diabetes } \\
\text { type }-1 \\
(\text { No. }=39)\end{array}$} & \multirow[t]{2}{*}{ Observed } & No. & 12 & 22 & 5 & 46 & 32 & \multirow[t]{4}{*}{0.300} \\
\hline & & $\%$ & 30.76 & 56.41 & 12.82 & \multicolumn{2}{|c|}{\begin{tabular}{l|r}
58.97 & 41.03 \\
Not Estimated
\end{tabular}} & \\
\hline & \multirow[t]{2}{*}{ Expected } & No. & 13.56 & 18.87 & 6.56 & \multirow{2}{*}{\multicolumn{2}{|c|}{ Not Estimated }} & \\
\hline & & $\%$ & 34.78 & 48.39 & 16.83 & & & \\
\hline \multirow{4}{*}{$\begin{array}{r}\text { Controls } \\
(\text { No. }=21)\end{array}$} & \multirow[t]{2}{*}{ Observed } & No. & 8 & 9 & 4 & 25 & 17 & \multirow[t]{4}{*}{ N.S. } \\
\hline & & $\%$ & 38.09 & 42.85 & 19.04 & $\mathbf{5 9 . 5 2}$ & 40.48 & \\
\hline & \multirow[t]{2}{*}{ Expected } & No. & 7.44 & 10.12 & 3.44 & \multirow{2}{*}{\multicolumn{2}{|c|}{ Not Estimated }} & \\
\hline & & $\%$ & 35.43 & 48.19 & 16.38 & & & \\
\hline
\end{tabular}

Table 2-: Statistical analysis of associations between IL-10-1082 genotypes or alleles in Type 1 Diabetes patients and controls.

\begin{tabular}{|c|c|c|c|c|c|}
\hline \multirow[b]{2}{*}{ Type of Comparison } & \multicolumn{3}{|c|}{ Statistical Evaluation } & \multirow[b]{2}{*}{$\begin{array}{c}\text { Fisher's } \\
\text { Exact } \\
\text { Probability }\end{array}$} & \multirow[b]{2}{*}{$\begin{array}{c}95 \% \\
\text { Confidence } \\
\text { Intervals }\end{array}$} \\
\hline & $\begin{array}{l}\text { IL-10-1082 } \\
\text { Genotype } \\
\text { or Allele }\end{array}$ & $\begin{array}{c}\text { Relative } \\
\text { Risk }\end{array}$ & $\begin{array}{l}\text { Preventive } \\
\text { or } \\
\text { Fraction } \\
\text { Etiological }\end{array}$ & & \\
\hline \multirow{5}{*}{$\begin{array}{c}\text { Diabetes Disease } \\
\text { Versus } \\
\text { Controls }\end{array}$} & GG & 10.6 & 0.72 & 0.579 & $0.24-2.15$ \\
\hline & GA & 23.7 & 1.73 & 0.418 & $0.60-4.93$ \\
\hline & AA & 7.1 & 0.63 & 0.706 & $0.05-0.55$ \\
\hline & $G$ & 1.3 & 0.98 & 1.000 & $0.46-2.08$ \\
\hline & $A$ & 0.9 & 1.02 & 1.000 & $0.48-2.18$ \\
\hline
\end{tabular}

\section{Discussion}

According to the presented results, $I L 10_{-1082}$ SNP can be highlighted as an important genetic marker in the pathogenesis of T1D, presented with three genotypes (GG, GA and AA) that corresponded to two alleles ( $G$ and $A$ ). These genotypes were significantly deviated in patients $(\mathrm{P} \leq 0.300)$, but they were a good agreement with Hardy-Weinberg equilibrium (HWE) in controls, the study illustrated that IL- $0_{-1082}$ important genetic marker in the pathogenesis of T1D especially if we consider RR values was 23.7 and 10.6 for it was showed that frequency of GA genotype and $A$ allele $(56.41 v s .41 .03 \% ; \mathrm{P}=0.418$ respectively) were significantly in patients in contrast to controls, $(42.85 \mathrm{vs} .40 .48 \%$; $\mathrm{P}$ $=1.000$ ), and the associated EF values were 1.73 and 1.02 , respectively. In contrast, GG genotype and $G$ allele (30.76vs. 58.97\%, $\mathrm{P}=0.579$ respectively) frequencies were significantly decreased in patients, compared to controls (38.09 vs. 59.52\%; $\mathrm{P}=1.000)$, and the associated PF values were 0.72 and 0.98 respectively. Similar observations were made in AA genotype. The present results strongly suggest that $I L-10-{ }_{1082}$ polymorphism showed associations (positive and negative) with T1D in the samples of Iraqi patients, due to IL-10 may act as regulatory for inhibition of pro inflammatory cytokines as (TNF- $\alpha$ ) and IL-1, increased serum concentration of inflammatory markers has been found in DM1 and DM2 patients, which seems to predict the onset and progression of diabetic complications 
$[8,11,13,14,22]$ this study agree with Previous studies suggest the role of IL-10 in diabetes it has been primarily directed toward the pancreatic cells and the pathogenesis of type 1diabetes. Prevention was associated with an increased production of IL-10 from Payer's patches and the spleen and with increased IL-10 expression in the pancreas, [12,16,19,28]. As well that IL-10 treatment significantly reduced insulitis and prevented the intracellular signaling in vivo [25]. This study was agreed with other studies who suggested role for I L10 in T1D development when IL-10 decreased in patients [26, 23, 21]. Therefore, the functional role of such $I L 10_{-1082}$ might have been altered due to the deviations of some genotype and allele frequencies in this study.

\section{References:}

1- Ozougwu, J. C.; Obimba, K. C.; Belonwu, C. D.; and Unakalamba, C. B.(2013). The pathogenesis and pathophysiology of type 1 and type 2 diabetes mellitus. J. Physiology and Pathophysiology, Vol. 4(4), pp. 46-57.

2- Bonifacio, E. (2015).Predicting Type 1 Diabetes Using Biomarkers. J. Diabetes Care Jun; 38(6): 989-996.

3- Araújo, L. S. ; da Silva, M. V. ; da Silva, C. A. ; Monteiro, M. R . ; de Morais Pereira, L. H. ; Rocha, L. P. ; Miranda Corrêa, R. R. ; Reis, M. A. and Machado, J. R. (2016) .Cytokines and T Helper Cells in Diabetic Nephropathy Pathogenesis. J. Diabetes Mellitus, , 6, 230-246.

4-Kikodze, N. ; Pantsulaia, I. ; Rekhviashvili, K. h. ; Iobadze, M. ; Dzhakhutashvili, N. ; Pantsulaia, N. ; Kukuladze, N. ; Bikashvili, N. ; Metreveli, D. and Chikovani, T.(2013). Cytokines and $\mathrm{T}$ regulatory cells in the pathogenesis of type 1 diabetes. Georgian Med News. Sep ;(222):29-35.

5- Gustavsson, C.(2010). Inflammatory mediators in diabetic retinopathy. Published: 01/01. Citation for published version (APA):PP.1-133.

6- Fichtlscherer, S. ; Breuer, S. ; Heeschen, C. ; Dimmeler, S.and Zeiher, A M.(2004). Interleukin-10 Serum Levels and Systemic Endothelial Vasoreactivity in Patients with Coronary Artery Disease. J. American College of Cardiology, Vol. 44, No. 1, July 7,:44-9.

7- Roep, B. O. ; Kleijwegt, F. S. ; van Halteren, A. G.; Bonato, S. V .; Boggi, U .; Vendrame, F. ; Marchetti, P. and Dotta, F. (2010) .Islet inflammation and CXCL10 in recent-onset type 1 diabetes. Clin Exp Immunol. Mar; 159(3): 338-343.

8- Bijjiga, E. and Martino, A.T. (2013) Interleukin 10 (IL-10) Regulatory Cytokine and its Clinical Consequences. J. Clin Cell Immunol S1: 007.

9- Ueki, I.; Abiru, N. ; Kawagoe, K. and Nagayama, Y .(2011) Interleukin 10 deficiency attenuates induction of anti-TSH receptor antibodies and hyperthyroidism in a mouse Graves' model. $J$. Endocrinology 209, 353-357 .

10- Arend,W.P.;Palmer, C. and Gabay, C.(2008).IL-1,IL-18, and IL-23 families of cytokines. Immunol. Rve., 223:20-38.

11- . Erdogan, M. ; Cetinkalp, S. ; Ozgen, A. G. ; Saygili, F. ; Berdeli, A. and Yilmaz, C.( 2012) Interleukin-10 (-1082G/A) Gene Polymorphism in Patients With Type 2 Diabetes With and Without Nephropathy. Genetic Testing and Molecular Biomarkers. February, 16(2): 91-94.

12- Hong, E. G .; Ko, H. J. ; Cho, Y.R .; Kim, H.J. ; Ma, Z . ; Yu, T. Y.; Friedline, R. H. ; Jones, E. K. ; Finberg, R .; Fischer, M. A. ; Granger, E. L. ; Norbury, C. C. ; Hauschka, S D. ; 


\section{AL-Qadisiyah Journal of pure Science Vol.23 No. $1 \quad$ Year 2018}

Philbrick, W. M. ; Lee, C.G. ; Elias, J. A. and Kim, J. K.( 2009). Interleukin-10 Prevents Diet-Induced Insulin Resistance by Attenuating Macrophage and Cytokine Response in Skeletal Muscle DIABETES, VOL. 58, NOVEMBER:2525-2536.

13- Mahmoud, A.A. ; Sheneef, A. ; Sayed, A.A. ; Ezat ,M.A.W. and Sabet, E.A. (2016). Association of Interleukin-10 (-592A/C) Gene Polymorphism with its Level in Type 2 Diabetes Mellitus with and without Nephropathy. J Mol Genet Med 10:199.

14- Hua, Y. ; Shen, J. ; Song, Y. ; Xing, Y. and Ye, X. (2013) Interleukin-10-592C/A, $-819 \mathrm{C} / \mathrm{T}$ and $-1082 \mathrm{~A} / \mathrm{G}$ Polymorphisms with Risk of Type 2 Diabetes Mellitus: A HuGE Review and Meta-analysis. PLoS ONE 8(6): e66568.

15- Soren, K. and Grey, M.(2015). Depression, Anxiety, and Eating Disorders Are Common in Teens and Young Adults with Type 1 Diabetes. Vertical Health, LLC. http://www.endocrineweb.com.

16- Ma, D.H. ; Xu, Q.Y. ; Liu1, Y.; Zhai Q.Q. and Guo, M.H. (2016).Association between interleukin-10 gene polymorphisms and susceptibility to diabetic nephropathy in a Chinese population. Genetics and Molecular Research 15 (2): gmr.15027570.

17- Kyi, M. ; Wentworth, J. M. ; Nankervis, A. J.; Fourlanos, S. and Colman, P. G. (2015).Recent advances in type 1 diabetes. Med. J. Aust; 203 (7): 290-293.

18- Holan, V. ; Zajicova, A. ; Javorkova, E. ; Trosan, P. ; Chudickova, M. ; Pavlikova, M . and Krulova, M.(2014).Distinct cytokines balance the development of regulatory T cells and interleukin-10-producing regulatory B cells. Immunology. Apr; 141(4): 577-586.

19- Calcinaro, F. ; Dionisi, S. ; Marinaro, M. ; Candeloro, P. ; Bonato, V. ; Marzotti, S. ; Corneli, R. B. ; Ferretti ,E. ; Gulino, A. ; Grasso, F. ; De Simone, C. ; Di Mario, U. ; Falorni, A. and Boirivant, M. .(2005). Oral probiotic administration induces interleukin-10 production and prevents spontaneous autoimmune diabetes in the non-obese diabetic mouse. Diabetologia. Aug;48(8):1565-75.

20- Balasa, B. ; La Cava, A. ; Van Gunst, K. ; Mocnik, L. ; Balakrishna, D . ; Nguyen, N. ; Tucker, L. and Sarvetnick, N .(2000). A Mechanism for IL-10-Mediated Diabetes in the Nonobese Diabetic (NOD) Mouse: ICAM-1 Deficiency Blocks Accelerated Diabetes J Immunol; 165: 12.73307337.

21 Russell, M. A. and Morgan, N. G. (2014) The impact of anti-inflammatory cytokines on the pancreatic $\beta$-cell. Islets, 6:3, e950547,

22- Helaly, M. A-H. ; Hatata, E-S. Z. ; Abu-Elmagd, M. ; Ibrahem, E. F. ; Alsaid, A. ; Abd El-Aal, I. A . and Settin, A. (2013). Association of IL-10 and IL-6 Gene Polymorphisms with Type 2 Diabetes Mellitus among Egyptian Patients. Eur J. Gen .Med.;10(3):158-162.

23- Goudy, K. ; Song, S. ; Wasserfall, C. Y.; Zhang, C. ; Kapturczak, M. ; Muir, A. ; Powers, Scott-Jorgensen,M . M . ; Campbell-Thompson, M . ; Crawford, J. M. ; Ellis, T. M.. ; Flotte, T. R. and Atkinson, M. A. ( 2001). Adeno-associated virus vector-mediated IL-10 gene delivery prevents type 1 diabetes in NOD mice. PNAS _ November 20, _ vol. 98 _ no. 24 _ 13913-13918.

25-Youssef, A.R. and Elson C.J. (2017). Induction of IL-10 cytokine and the suppression of T cell proliferation by specific peptides from red cell band 3 and in vivo effects of these peptides on utoimmune hemolytic anemia in NZB mice. Auto Immun Highlights. Dec;8(1):7. doi:10.1007/s13317017-0095-4. 
AL-Qadisiyah Journal of pure Science $\quad$ Vol.23 No. $1 \quad$ Year 2018

26-Mi, Q.S. ; Ly, D. ; Zucker, P. ; McGarry, M. and Delovitch, T. L. (2004). Interleukin-4 but not Interleukin-10 Protects Against Spontaneous and Recurrent Type 1 Diabetes by Activated CD1dRestricted Invariant Natural Killer T-Cells. Diabetes, May; 53(5): 1303-1310.

27- Cordeiro, C. A.; Moreira, P. R.; Andrade, M. S. ; Dutra, W. O. ; Campos, W. R.; Oréfice, F. andTeixeira, A. L. (2008). Interleukin-10 Gene Polymorphism (-1082G/A) is Associated with Toxoplasmic Retinochoroiditis. Investigative Ophthalmology \& Visual Science May, Vol.49, 1979-1982.

28- Peng, X. ; Xu, J. ; Wang, P. ; Zhou, J. and Guo, H .( 2015).Interleukin-10-1082A/G Polymorphism and Diabetic Nephropathy: A Meta-Analysis. Med Sci Monit.; 21: 890-894. 